\title{
Particle Filter in State Vector Estimation Problem for Power System
}

\author{
Piotr Kozierski ${ }^{\star}$, Marcin Lis ${ }^{\star *}$, Joanna Ziętkiewicz* \\ *Institute of Control and Information Engineering, Faculty of Electrical Engineering, \\ Poznan University of Technology \\ ${ }^{* *}$ Institute of Electrical Engineering and Electronics, Faculty of Electrical Engineering, \\ Poznan University of Technology
}

\begin{abstract}
Particle Filter is a tool, which has been used more frequently over the years. Calculations with using Particle Filter methods are very versatile (in comparison to the Kalman Filter), which can be used in high complex and nonlinear problems. Example of such a problem is the power system, where Particle Filter is used to state estimation of network parameters based on measurements. Paper presents theoretical basis regarding Particle Filter and power system state estimation. Results of experiment have shown that Particle Filter usually gives better outcome comparing to the Weighted Least Squares method. In extension Multi Probability Density Function Particle Filter is proposed, which improves obtained results so that they are always better than Weighted Least Squares method.
\end{abstract}

Keywords: particle filter, state observer, state estimation, power system, weighted least squares

DOI: 10.14313/PAR_203/76

\section{Introduction}

Particle Filter has been used for about 20 years. It was caused by high computational requirements, especially in high-dimensional objects. In relation to this, PF usefulness grows with the development of technology and computational power. In addition, advantage of $\mathrm{PF}$ is its easiness to implement parallel computing, which in recent years is becoming more and more popular [15]. Good implementation with the use of FPGA systems allows to reduce computation time even by few magnitude orders [13].

$\mathrm{PF}$, on the contrary of Kalman Filter, can be used to linear and nonlinear objects, but in practice it is used only to high nonlinear problems.

In the following article, nonlinear, multidimensional object - power system was chosen. This is one of a few attempts that can be found in literature to use PF in such as complex problem - in given task, there are 14 state variables and even more input signals.

Second chapter introduces particle filter operation principle. Third chapter is devoted to state estimation of power system. Fourth chapter describes proposed power network and explains how the object was modelled. Simulation results are shown in fifth chapter. In the sixth chapter Multi PDF PF is proposed and simulation results are shown.

\section{Particle Filter}

$\mathrm{PF}$ principle of operations is based on Bayesian estimation and is one of the possible implementations of Recursive Bayesian Filter [3]

$\overbrace{p(\boldsymbol{x}(k) \mid \boldsymbol{Y}(k))}^{\text {posterior }}=\frac{\overbrace{p(\boldsymbol{y}(k) \mid \boldsymbol{x}(k))}^{\text {likelihood }} \cdot \overbrace{p(\boldsymbol{x}(k) \mid \boldsymbol{Y}(k-1))}^{\text {prior }}}{\underbrace{p(\boldsymbol{y}(k) \mid \boldsymbol{Y}(k-1))}_{\text {evidence }}}$

where prior probability density function $(\mathrm{PDF})$ is given by

$p(\boldsymbol{x}(k) \mid \boldsymbol{Y}(k-1))=$

$=\int p(\boldsymbol{x}(k) \mid \boldsymbol{x}(k-1)) \cdot p(\boldsymbol{x}(k-1) \mid \boldsymbol{Y}(k-1)) d \boldsymbol{x}(k-1)$

In (1-2) assumed that $\boldsymbol{x}(k)$ represents state vector in time step $k, \boldsymbol{y}(k)$ is the measurement vector in time step $k$, and

$$
\boldsymbol{Y}(k)=\{\boldsymbol{y}(1), \boldsymbol{y}(2), \ldots, \boldsymbol{y}(k)\}
$$

The uniqueness of this implementation is caused by represent posterior density by set of particles, where each has values $\boldsymbol{x}^{i}(k)$ and weight $q^{i}(k)$. Set of all particles $\left\{\boldsymbol{x}^{i}(k), q^{i}(k)\right\}$ $i=1, \ldots, N$ gives information about PDF $p(\boldsymbol{x}(k) \mid \boldsymbol{Y}(k))$

$$
p(\boldsymbol{x}(k) \mid \boldsymbol{Y}(k)) \approx \hat{p}(\boldsymbol{x}(k) \mid \boldsymbol{Y}(k))=\sum_{i=1}^{N} q^{i}(k) \cdot \boldsymbol{x}^{i}(k)
$$

Based on strong law of large numbers, it can be written that

$$
p(\boldsymbol{x}(k) \mid \boldsymbol{Y}(k)) \stackrel{N \rightarrow \infty}{=} \sum_{i=1}^{N} q^{i}(k) \cdot \boldsymbol{x}^{i}(k)
$$


Each iteration in PF algorithm consists of two parts: prediction and update (respectively (2) and (1)). Transition density $p(\boldsymbol{x}(k) \mid \boldsymbol{x}(k-1))$ and likelihood $p(\boldsymbol{y}(k) \mid \boldsymbol{x}(k))$ are given with the knowledge of the system.

PF algorithm was proposed in 1993 by Gordon, Salmond and Smith [8] and it was named Bootstrap Filter. It is one of SIR (Sequential Importance Resampling) algorithms varieties, which is very simple to implement. Bootstrap Filter operation principle is shown below.

\section{Algorithm (Bootstrap Filter)}

1. Initialization. Draw $N$ particles from initial density $\boldsymbol{x}^{i}(0) \sim p(\boldsymbol{x}(0))$. Set initial particle weights $q^{i}(0)=1 /{ }_{N}$ and initial time step $k=1$.

2. Prediction. Draw particles from importance density $\boldsymbol{x}^{i}(k) \sim p\left(\boldsymbol{x}(k) \mid \boldsymbol{x}^{i}(k-1)\right)$.

3. Update. Compute weights values of all particles using expression $q^{* i}(k)=p\left(\boldsymbol{y}(k) \mid \boldsymbol{x}^{i}(k)\right)$.

4. Normalization. Normalize weights so that the sum is equal 1.

5. Resampling. Draw new particles set based on posterior PDF.

6. Iteration end. Compute state estimation using (4). Time step update $k=k+1$. Go to step 2 .

Information about PF were presented very briefly. Additional knowledge and more accurate description can be found in literature. A very extensive publication is [5], but it is recommended only for the experienced particle filter designers. If one would like to learn basics, it is suggested to read [2, 10 or 14]. Position [16] is also recommended because of rich illustrations and wide description of the use $\mathrm{PF}$ in robotics.

\section{Power system state estimation}

There exist lots of power systems worldwide. Each of them supplies electrical energy to thousands or millions of people and each of them requires estimation of its internal state. Thanks to the information of power distributor it is possible to calculate power flow in network, protect it of any possible failures $(N-1$ rule - system is able to withstand the loss of any single component [12]) and find optimal power flow $(\mathrm{OPF})$ in order to minimize losses and costs of energy production $[9,18]$.

Estimation goal is to obtain state vector $\boldsymbol{x}$ based on measurements $\boldsymbol{y}$, which are (generally) nonlinearly dependent on the state

$$
y=h(x)+n
$$

In equation (6) $\boldsymbol{h}(\boldsymbol{x})$ means a true values vector of measured parameters, $\boldsymbol{y}$ is a measurement vector, and $\boldsymbol{n}$ is a measurement noise vector. State vector in power system is a set of nodal voltage magnitudes and angles

$$
\begin{aligned}
& \boldsymbol{x}=\left[\begin{array}{llll}
x_{1} & x_{2} & \ldots & x_{2 B}
\end{array}\right]^{T}= \\
& =\left[\begin{array}{llllll}
U_{1} & \ldots & U_{B} & \delta_{1} & \ldots & \delta_{B}
\end{array}\right]^{T}
\end{aligned}
$$

where $B$ is a number of all network buses (nodes).
Buses are linked by lines with a certain admittance

$$
\underline{y}_{i j}=\frac{1}{\underline{Z}_{i j}}=\frac{1}{R_{i j} \quad j X_{i j}}
$$

where $R_{i j}$ and $X_{i j}$ are resistance and reactance between $i$-th and $j$-th buses. Based on (8), the admittance matrix of size $B \times B$ is created according to

$$
\begin{gathered}
\underline{Y}_{i j}=\underline{y}_{i j} \quad i \quad j \\
\underline{Y}_{i i}=\underbrace{B}_{\substack{j=1 \\
j i}} \frac{y_{i j}}{2} \quad \underline{y}_{i j}
\end{gathered}
$$

Based on Euler's formula, the following notation can be assumed

$$
\begin{gathered}
\underline{U}_{i}=U_{i} \cdot \exp \left(j \delta_{i}\right) \\
\underline{Y}_{i j}=Y_{i j} \exp \left(j_{i j}\right)
\end{gathered}
$$

Usually measured values are the powers (nodal and flow) and voltages (magnitude). In the calculations it is possible to take into account the currents, but in practice it was never used on a wide scale [11]. The relationship between all types of measurements and state vector (admittance values are given together with the network topology) is given by [1]:

- real and reactive power injection at bus $i$

$$
\begin{gathered}
P_{i}(\boldsymbol{U}, \delta)=P_{i}={ }_{j=1}^{B} U_{i} U_{j} Y_{i j} \cos \left({ }_{i}{ }_{j}-{ }_{i j}\right) \\
Q_{i}(\boldsymbol{U}, \delta)=Q_{i}=\sum_{j=1}^{B} U_{i} U_{j} Y_{i j} \sin \left(\delta_{i}-\delta_{j}-\mu_{i j}\right)
\end{gathered}
$$

- real and reactive power flow from bus $i$ to bus $j$

$$
\begin{aligned}
& P_{i j}(\boldsymbol{U}, \delta)=P_{i j}= \\
& =U_{i}^{2} Y_{i j} \cos \left(-\mu_{i j}\right)-U_{i} U_{j} Y_{i j} \cos \left(\delta_{i}-\delta_{j}-\mu_{i j}\right) \\
& Q_{i j}(\boldsymbol{U}, \delta)=Q_{i j}=U_{i}^{2} Y_{i j} \sin \left(-_{i j}\right)+ \\
& -U_{i} U_{j} Y_{i j} \sin \left({ }_{i}-{ }_{j}-{ }_{i j}\right)+U_{i}^{2} \frac{y_{i j}}{2}
\end{aligned}
$$

In expression (16) $y_{i j}^{\prime} / 2$ there is the half total line charging susceptance [19]. A special case is the voltage measure, which is linearly dependent on the state vector (one of a state variable is measured directly).

One may notice the difference of phase angles in each equation. It is required to choose the reference angle, that will be constant $\delta_{r}=0$. By doing that state vector dimension is decreased by 1 . 


\subsection{Weighted least squares estimation method}

In order to estimate the state vector, weighted least squares (WLS) method was used. It assumes the knowledge about initial state $\boldsymbol{x}(0)$. Goal of this method (like in PF) is a selection of state $\boldsymbol{x}$, so sum of squares between measured value and calculated one based on $\boldsymbol{x}$ was as low as possible. Formally it can be written as

$$
\min _{x} J(x)=\min _{x}\left(\boldsymbol{y}-\boldsymbol{h}(\boldsymbol{x})^{T} \boldsymbol{W} \boldsymbol{y}-\boldsymbol{h}(\boldsymbol{x})\right)
$$

where $\boldsymbol{h}(\boldsymbol{x})$ is the value vector calculated from state variables and $W$ is weight matrix, which possesses the elements only on diagonal

$$
W=\left[\begin{array}{cccc}
1 / \sigma_{1}^{2} & 0 & \cdots & 0 \\
0 & 1 / \sigma_{2}^{2} & \cdots & 0 \\
\vdots & \vdots & \ddots & \vdots \\
0 & 0 & \cdots & 1 / \sigma_{m}^{2}
\end{array}\right]
$$

where $\sigma_{i}^{2}$ is noise variance $i$-th measure, $m$ is a number of all measurements in network.

Iteration equation to calculate state variables is given by expression

$$
\begin{aligned}
& \boldsymbol{x}^{(t)}=\boldsymbol{x}^{(t)} \quad \boldsymbol{x}^{(t)} \\
& \boldsymbol{x}^{(t)} \quad \boldsymbol{H}^{T} \boldsymbol{W} \boldsymbol{H}^{-1} \boldsymbol{H}^{T} \boldsymbol{W} \boldsymbol{y}-\boldsymbol{h}\left(\boldsymbol{x}^{(t)}\right)
\end{aligned}
$$

where $\boldsymbol{H}$ is Jacobi matrix, therefore it is a partial derivatives matrix

$$
\begin{aligned}
& h_{1}\left(\boldsymbol{x}^{(t)}\right) /_{x_{1}} \quad \cdots \quad h_{1}\left(\boldsymbol{x}^{(t)}\right) /_{x_{2 B-1}}
\end{aligned}
$$

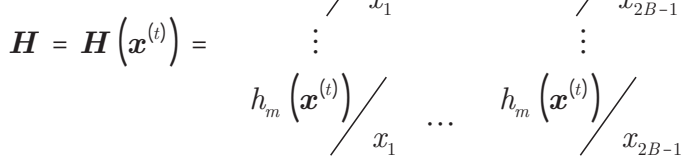

Formula derivation (19) is available in [1, 7 and 11].

\section{Simulated system}

In simulation, the 7-node network was used, proposed in [17], which is presented in fig. 1. Parameters of the network were shown in table 1 , and initial state of the system in table 2 . On fig. 1 . were marked the places from which the measures were taken. One can see that the bus 5 does not have any measurements, but overall the state vector can be estimated correctly.

In case of $\mathrm{PF}$, the system was written in a form of equations:

$$
\begin{gathered}
x_{1}^{k}=x_{1}^{k-1} \quad v_{1}^{k-1} \quad u_{1}^{k-1} \quad p_{1}^{k-1} \\
\vdots \\
x_{2 B-1}^{k}=x_{2 B-1}^{k-1} \quad v_{2 B-1}^{k-1} \quad u_{2 B-1}^{k-1} \quad p_{2 B-1}^{k-1} \\
y_{1}^{k}=h_{1}\left(x^{k}\right) \quad n_{1}^{k} \\
\vdots \\
y_{m}^{k}=h_{m}\left(x^{k}\right) \quad n_{m}^{k}
\end{gathered}
$$

where $k-1$ means the previous time step, $\boldsymbol{u}$ is the control vector, whereas $v, p$ and $n$ are noises - respectively system, control and measurement (all of them are Gaussian).

The modelled system has 13 state variables (assumption was made that first node is reference, so angle $\delta_{1}$ is not included into state variables), 13 input signals and 32 output signals (because measurement occurs in 32 places in the system).

There is a need to explain what control and noise control is. Particle filter has possibility to observe state of the system not only from its outputs but also from using input signals. In relation to this, assumption can be made that one knows certain control signal, which modifies values of state variables from previous time step. This control signal can be realized by preliminary assessment, what value can be. For simplicity assumed that this information is available, but also that it has high control noise (error) of approximately $20 \%$.

In case of WLS calculation was conducted according to formula (19).

The measurement noise standard deviation was set to $\sigma_{n}=0.01$ for all kind of measures (calculations were made in relative units). System noise standard 
deviation was set to $\sigma_{v U}=0.0005$ for voltage magnitude and $\sigma_{\imath \delta}=0.0002$ for voltage angles. Control noise standard deviation was set to $\sigma_{p}=0.001$ for voltage magnitude and angle.

\section{Simulation results}

Power system from chapter 4 was used in simulations. Every simulation was conducted on the same data so that the comparison of algorithms could be possible. Each simulation consisted of 100 time steps. In the first time step the assumptions were made that the correct state of the system is well known, and the estimation begins from the second time step. PF implementation use a relatively small number of particles - 500 (some studies are using up to 10 times more particles $[4,6])$.

Simulation results are shown in table 3 . For WLS method, calculations were made only once (result is dependent only on measurement values), while for PF calculations, the simulations were made multiple times, each time a different random generator seed was used.

Results from table 3. regard the mean square errors (MSE) particular state variable in comparison to real values. Comparison factor $D$ was defined in form

$$
D={ }_{i=1}^{13}\left(M S E_{i} 10^{3}\right)^{2}
$$

Based on the results, one can state that the proposed approach with using PF is usually better than WLS. Few more simulations were performed with $\mathrm{PF}$ estimator and

Tab. 1. Parameters of the network

Tab. 1. Parametry sieci

\begin{tabular}{|c|c|c|c|c|}
\hline \multicolumn{2}{|c|}{ Line } & \multirow{2}{*}{$\begin{array}{c}R_{i j} \\
(\mathrm{pu})\end{array}$} & \multirow{2}{*}{$\begin{array}{r}X_{i j} \\
(\mathrm{pu})\end{array}$} & \multirow{2}{*}{$\begin{array}{l}y_{i j}^{\prime} / 2 \\
(\mathrm{pu})\end{array}$} \\
\hline From bus & To bus & & & \\
\hline 1 & 2 & 0.1 & 0.17 & 0.015 \\
\hline 1 & 6 & 0.18 & 0.22 & 0.02 \\
\hline 2 & 3 & 0.11 & 0.12 & 0.025 \\
\hline 2 & 6 & 0.12 & 0.25 & 0.03 \\
\hline 3 & 4 & 0.12 & 0.42 & 0.02 \\
\hline 3 & 5 & 0.14 & 0.39 & 0.02 \\
\hline 3 & 7 & 0.16 & 0.32 & 0.025 \\
\hline 4 & 5 & 0.08 & 0.30 & 0.015 \\
\hline 5 & 6 & 0.16 & 0.44 & 0.01 \\
\hline 6 & 7 & 0.09 & 0.23 & 0.01 \\
\hline
\end{tabular}

Tab. 2. Network initial state - voltage magnitudes and angles with calculated bus power injections in nodes

Tab. 2. Stan początkowy sieci - wartości napięć oraz kąty wraz z policzonymi mocami węzłowymi

\begin{tabular}{c|c|c|c|c|c|}
\hline Bus $i$ & Type & $\begin{array}{c}U_{i} \\
(\mathrm{pu})\end{array}$ & $\begin{array}{c}\delta_{i} \\
(\mathrm{pu})\end{array}$ & $\begin{array}{c}P_{i} \\
(\mathrm{pu})\end{array}$ & $\begin{array}{c}Q_{i} \\
(\mathrm{pu})\end{array}$ \\
\hline 1 & Gen. & 1.0800 & 0 & 0.3497 & 0.2949 \\
\hline 2 & Gen. & 1.0609 & 0.0254 & 0.2380 & 0.2140 \\
\hline 3 & Gen. & 1.0577 & 0.0826 & 1.6840 & 0.1000 \\
\hline 4 & Load & 0.9364 & -0.0941 & -0.5650 & -0.1630 \\
\hline 5 & Load & 0.9556 & -0.0561 & -0.2760 & -0.1390 \\
\hline 7 & Load & 0.9768 & -0.0594 & -0.7480 & -0.1970 \\
\hline 7 & Load & 0.9557 & -0.0626 & -0.5150 & -0.1380 \\
\hline
\end{tabular}

Tab. 3. State variables mean square errors for WLS method and few cases for PF method

Tab. 3. Średnie kwadraty błędów zmiennych stanu dla metody WLS i kilku przykładów metody PF

\begin{tabular}{|l|l|l|l|l|l|}
\hline & WLS & \multicolumn{4}{|c|}{$\mathrm{PF}$} \\
\hline $\mathrm{MSE}_{1}\left[\cdot 10^{3}\right]$ & 1.3698 & 0.9160 & 1.1415 & 2.2406 & 0.4788 \\
\hline $\mathrm{MSE}_{2}\left[\cdot 10^{3}\right]$ & 1.4266 & 0.9617 & 1.2746 & 2.5152 & 0.3827 \\
\hline $\mathrm{MSE}_{3}\left[\cdot 10^{3}\right]$ & 1.4570 & 0.7700 & 1.1688 & 2.4141 & 0.5030 \\
\hline $\mathrm{MSE}_{4}\left[\cdot 10^{3}\right]$ & 2.7357 & 1.4754 & 2.4768 & 3.6361 & 1.5286 \\
\hline $\mathrm{MSE}_{5}\left[\cdot 10^{3}\right]$ & 2.4636 & 1.5588 & 1.4469 & 4.1565 & 1.9055 \\
\hline $\mathrm{MSE}_{6}\left[\cdot 10^{3}\right]$ & 1.6126 & 1.4196 & 1.6230 & 2.8377 & 0.3849 \\
\hline $\mathrm{MSE}_{7}\left[\cdot 10^{3}\right]$ & 2.3258 & 1.7501 & 2.1074 & 2.6905 & 0.7610 \\
\hline $\mathrm{MSE}_{8}\left[\cdot 10^{3}\right]$ & 0.0756 & 0.0750 & 0.0794 & 0.0576 & 0.0715 \\
\hline $\mathrm{MSE}_{9}\left[\cdot 10^{3}\right]$ & 0.2667 & 0.1849 & 0.3381 & 0.1615 & 0.1508 \\
\hline $\mathrm{MSE}_{10}\left[\cdot 10^{3}\right]$ & 1.2264 & 0.6167 & 0.5928 & 1.3581 & 0.3391 \\
\hline $\mathrm{MSE}_{11}\left[\cdot 10^{3}\right]$ & 2.0179 & 1.3918 & 1.0928 & 0.7290 & 0.5500 \\
\hline $\mathrm{MSE}_{12}\left[\cdot 10^{3}\right]$ & 0.2502 & 0.1975 & 0.2163 & 0.2673 & 0.1781 \\
\hline $\mathrm{MSE}_{13}\left[\cdot 10^{3}\right]$ & 4.3421 & 1.8099 & 2.4802 & 2.4597 & 2.6429 \\
\hline$D$ & 52.1666 & 17.7135 & 27.4613 & 71.4915 & 14.7852 \\
\hline
\end{tabular}


it was calculated that the mean value $D$ from $\mathrm{PF}$ is around 26.5 , so it is significantly superior to WLS method (which is around 52.2).

\section{Multi PDF Particle Filter}

Based on results presented in tab. 3 one can see that one of few $\mathrm{PF}$ simulation result is not satisfactory. This problem can be solve by parallel running of several particle filters and averaging estimation results. But this approach would involve a more time for computations - three particle filters will worked 3 times longer on the standard CPU.

Therefore decided to check how 3 independent particle filters with $N / 3$ particles would worked.

\subsection{Principle of operation}

Assumption has been made that posterior PDF of every PF are completely independent and affect only for estimation result by calculating average value from these 3 estimated state vectors. Based on (4) can be written

$$
\begin{aligned}
& p(\boldsymbol{x}(k) \mid \boldsymbol{Y}(k))= \\
& =\frac{p_{1}(\boldsymbol{x}(k) \mid \boldsymbol{Y}(k)) \quad p_{2}(\boldsymbol{x}(k) \mid \boldsymbol{Y}(k)) \quad p_{3}(\boldsymbol{x}(k) \mid \boldsymbol{Y}(k))}{3}
\end{aligned}
$$

where $p_{a}(\boldsymbol{x}(k) \mid \boldsymbol{Y}(k))$ is a posterior of $a$-th PF.

Every of these partial particle filters has 166 particles, so computational time is similar to one PF composed of 500 particles.

All other elements, including power system, remained unchanged.

\subsection{Results}

100 simulations with different seed were performed, both Multi PDF PF method and standard PF with 500 particles. Results of simulations are shown in tab. 4 . The same results are presented in fig. 2 (all values refer to the factor $D$, described in (22)).

Based on obtained results one can see that the use of Multi PDF PF provides almost 2-fold improvement in

Tab. 4. Results of 100 simulations

Tab. 4. Wyniki 100 symulacji

\begin{tabular}{|c|c|c|}
\hline & $\begin{array}{c}\text { Multi PDF PF } \\
(3 \times 166 \text { particles })\end{array}$ & $\begin{array}{c}\text { PF } \\
(1 \times 500 \text { particles })\end{array}$ \\
\hline Mean & 15.8753 & 25.7054 \\
\hline Min & 4.2183 & 4.2651 \\
\hline Max & 50.5057 & 79.0455 \\
\hline$\sigma^{2}$ & 70.1732 & 301.0310 \\
\hline$\sigma$ & 8.3769 & 17.3502 \\
\hline
\end{tabular}

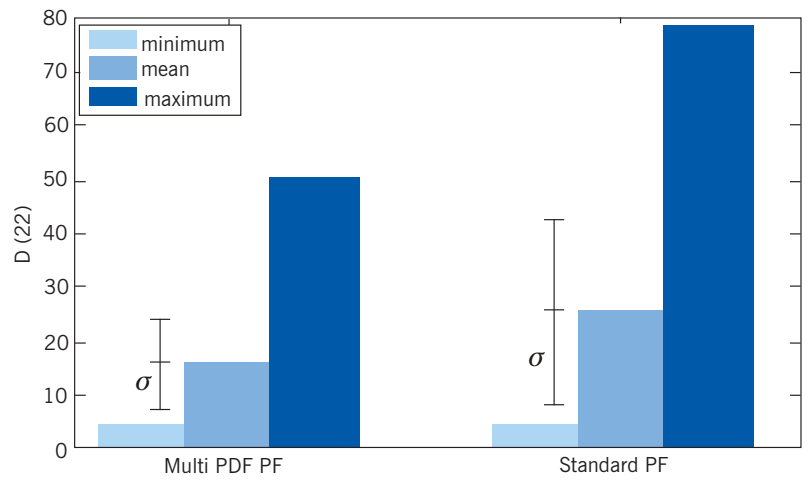

Fig. 2. Results of 100 simulations

Rys. 2. Wyniki 100 symulacji

performance. Maximum performance has been reduced (from 79 to 50.5), which was the main aim of the proposed method, but also the minimum value has improved. By reducing the maximum value also much smaller variance of the results were achieved.

\section{Summary}

In the article, a new approach is presented in order to state variable estimation in the power system with using the particle filter. Based on performed simulations it can be concluded that this new approach offers better results than standard WLS algorithm.

In the future studies, the presented algorithm will be expanded by preliminary state estimation. There will be also the implementation of more complex algorithms. It is planned to develop more the estimation subject because of the algorithm's susceptibility to gross errors, the lack of some the measurements and the loss of observability.

In extension new approach was presented - Multi PDF Particle Filter. Simulation results shown that this approach is better than basic PF.

\section{Bibliography}

1. Abur A., Exposito A.G., Power System State Estimation: Theory and Implementation, Marcel Dekker, Inc., 2004, 17-49.

2. Arulampalam S., Maskell S., Gordon N., Clapp T., A Tutorial on Particle Filters for On-line Non-linear/Non-Gaussian Bayesian Tracking, "IEEE Proceedings on Signal Processing", Vol. 50, 2/2002, 174-188.

3. Candy J.V., Bayesian signal processing, WILEY, New Jersey 2009, 36-44.

4. Carpenter J., Clifford P., Fearnhead P., Improved particle filter for nonlinear problems, "IEE Proceedings Radar, Sonar and Navigation", Vol. 146, 1/1999, 2-7.

5. Doucet A., Freitas N., Gordon N., Sequential Monte Carlo Methods in Practice, Springer-Verlag, New York 2001, 225-246.

6. Doucet, A., Tadić, V.B., Parameter Estimation in General State-Space Models using Particle Methods, 
"Annals of the institute of Statistical Mathematics", Vol. 52, 2/2003, 409-422.

7. Fardanesh, B., Zelingher, S., Power system state estimation: modeling error effects and impact on system operation, Proceedings of the Hawaii International Conference On System Sciences, January 2001, Maui, $1-9$.

8. Gordon N.J., Salmond N.J., Smith A.F.M., Novel approach to nonlinear/non-Gaussian Bayesian state estimation, IEE Proceedings-F, Vol. 140, 2/1993, 107-113.

9. Kashem M.A., Le A.D., Negnevitsky M., Ledwich G., Distributed Generation for Minimization of Power Losses in Distribution Systems, In Power Engineering Society General Meeting, June 2006, 1-8.

10. Kozierski P., Lis M., Filtr czasteczkowy w problemie śledzenia - wprowadzenie, ,Studia z Automatyki i Informatyki", Vol. 37, 2012, 79-94.

11. Kremens Z., Sobierajski M., Analiza systemów elektroenergetycznych, Wydawnictwa Naukowo-Techniczne, Warszawa, 1996, 39-191.

12. Krischen D., Strbac G., Why investments do not prevent blackouts, UMIST, Manchester, UK, 27 August 2003.

13. Mountney J., Obeid I., Silage D., Modular Particle Filtering FPGA Hardware Architecture for Brain Machine Interfaces, Conf Proc IEEE Eng Med Biol Soc. 2011, 4617-4620.

14. Simon D., Optimal State Estimation, WILEY-INTERSCIENCE, New Jersey 2006, 461-484.

15. Sutharsan S., Kirubarajan T., Lang T., McDonald M., An Optimization-Based Parallel Particle Filter for Multitarget Tracking, "IEEE Transactions on Aerospace and Electronic Systems", Vol. 48, 2/2012, 1601-1618.

16. Thrun S., Particle Filters in Robotics, Proceedings of the $17^{\text {th }}$ Annual Conference on Uncertainty in AI (UAI), 2002.

17. Tinney, W.F., Hart, C.E., Power flow solution by Newton's method, "IEEE Transactions on Power Apparatus and Systems", Vol. 86, 11/1967, 1449-1460.

18. Wang H., On the Computation and Application of Multi-Period Security-Constrained Optimal Power Flow for Real-Time Electricity Market Operations, Doctoral dissertation, Cornell University, May 2007.

19. Wood A.J., Wollenberg B., Power Generation, Operation and Control, John Wiley \& Sons Inc., 1996, 91-130.

\section{Wykorzystanie filtru cząsteczkowego do estymacji wektora stanu w sieci elektroenergetycznej}

Streszczenie: Filtr cząsteczkowy jest narzędziem, które z roku na rok jest coraz chętniej wykorzystywane. Dużą zaletą obliczeń wykorzystujących metody filtru cząsteczkowego jest ich duża uniwersalność - w przeciwieństwie do filtru Kalmana mogą być stosowane nawet w bardzo skomplikowanych i silnie nieli- niowych obiektach. Przykładem takiego układu jest sieć elektroenergetyczna, a problem, który został rozwiązany przy wykorzystaniu metody filtru cząsteczkowego to estymacja stanu sieci na podstawie pomiarów. W artykule przedstawiono podstawy teoretyczne dotyczące filtrów cząsteczkowych oraz estymacji stanu w sieci elektroenergetycznej. Przedstawiono także wyniki symulacji porównujących wyniki estymacji wykorzystujących zarówno standardową metodę, jak i metodę filtru cząsteczkowego. W wyniku przeprowadzonego doświadczenia stwierdzono, że zaproponowana metoda estymacji stanu w układzie jest na ogół lepsza od standardowej metody WLS (ważonych najmniejszych kwadratów). W rozszerzeniu zaproponowano filtr cząsteczkowy złożony z kilku funkcji gęstości prawdopodobieństwa, który polepsza estymację wektora stanu. Dzięki zastosowaniu algorytmu otrzymywane wyniki są zawsze lepsze od metody ważonych najmniejszych kwadratów.

Słowa kluczowe: filtr cząsteczkowy, obserwator stanu, estymacja stanu, sieć elektroenergetyczna

Artykuł recenzowany, nadesłany 24.06.2013 r., przyjęty do druku 3.12.2013 r.

\section{Piotr Kozierski, PhD student}

PhD student on Poznan University of Technology. He is interested in estimation and optimization. Schedule date for dissertation defence is June 2015.

e-mail: piotr.kozierski@gmail.com

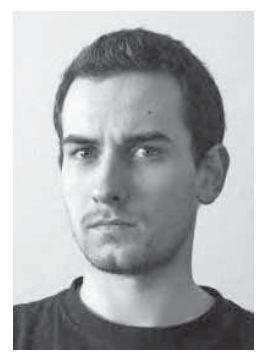

\section{Marcin Lin, PhD student}

PhD student on Poznan University of Technology. $\mathrm{He}$ is interested in control, neural networks and other heuristic computational methods. Schedule date for dissertation defence is June 2015.

e-mail:mail.dla.studenta@gmail.com

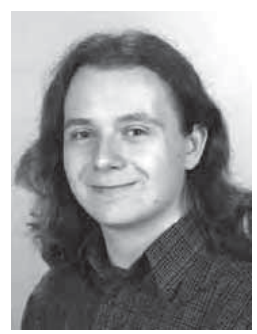

\section{Joanna Ziętkiewicz, PhD}

She is interested in predictive control methods for nonlinear muti-input multioutput systems with constraints. In particular she is concerning on using exact linearization methods. Moreover she works with system identification methods of linear and nonlinear objects.

e-mail: joanna.zietkiewicz@put.poznan.pl

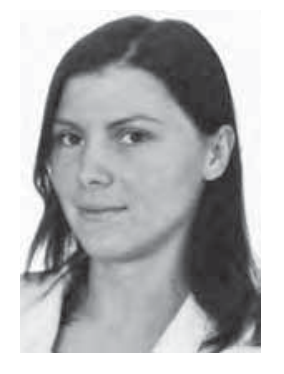

